Sains Malaysiana 50(8)(2021): 2229-2240

http://doi.org/10.17576/jsm-2021-5008-08

\title{
Viability of Lactobacillus plantarum TISTR 2083 in Protectant during Low- Temperature Drying and Storage
}

(Kelangsungan Lactobacillus plantarum TISTR 2083 dalam Pelindung semasa Pengeringan pada Suhu Rendah dan Penyimpanan)

\author{
Abdullah Al mamun, Payap Masniyom \& Jaruwan MANEesRi*
}

\begin{abstract}
Low-temperature drying was applied as simple and low cost drying technique for the production of dried Lactobacillus plantarum TISTR 2083, which was isolated from traditional starter of Ka-nom Tuay-fu. To improve the survival of L. plantarum TISTR 2083 during drying and storage, five different protectants and two carrier materials were investigated. These include sucrose, trehalose, maltodextrin, skim milk, and L-glutamate sodium salt (L-GSS) as protectant and rice starch and rice flour as carrier material. Whereas, skim milk as protectant with rice starch resulted in higher viable cell (8.71 log CFU/g) after drying by hot air oven at $40^{\circ} \mathrm{C}$. Different concentration 5,10 , and $15 \%(\mathrm{w} / \mathrm{v})$ skim milk also investigated to check the effect of skim milk concentration on cell viability. L. plantarum TISTR 2083 starter powder was in different storage conditions to check the storage stability. After 90 days of storage, starter powder stored at $4{ }^{\circ} \mathrm{C}$ with silica gel and without silica gel had more than $80 \%$ survival rate, while there was no viable cell that stored in room temperature with silica gel. The result showed the production and storage conditions of high viability $\mathrm{L}$. plantarum TISTR 2083, which can be used as starter culture for further fermented product development and as probiotic.

Keywords: Lactobacillus plantarum; low-temperature drying; protective agent; starter culture
\end{abstract}

ABSTRAK

Pengeringan suhu rendah digunakan sebagai teknik pengeringan yang mudah dan melibatkan kos yang rendah untuk penghasilan Lactobacillus plantarum TISTR 2083 jenis kering, yang dipencil daripada pemula tradisi Ka-nom Tuay-fu. Sehubungan dengan itu, bagi mempertingkat ketahanan sel L. plantarum TISTR 2083 semasa pengeringan dan penyimpanan, lima bahan pelindung dan dua bahan pembawa telah digunakan dalam uji kaji ini. Ini termasuk sukrosa, trehalosa, maltodekstrin, susu skim dan L-GSS sebagai pelindung. Pati beras dan tepung beras digunakan sebagai bahan pembawa. Manakala, susu skim yang digunakan sebagai bahan pelindung dengan pati beras menghasilkan sel yang lebih baik (8.71 log CFU/g) setelah dikeringkan dengan ketuhar udara panas pada suhu $40{ }^{\circ} \mathrm{C}$. Kepekatan susu skim yang berbeza 5, 10 dan 15\% (w/v) diuji untuk memeriksa kesan kepekatan susu skim terhadap ketahanan sel. Serbuk pemula L. plantarum TISTR 2083 berada dalam keadaan penyimpanan yang berbeza untuk memeriksa kestabilan penyimpanan. Setelah 90 hari penyimpanan, serbuk pemula yang disimpan pada suhu $4{ }^{\circ} \mathrm{C}$, dengan gel silika dan tanpa gel silika mempunyai kadar kelangsungan hidup lebih daripada $80 \%$, sementara tiada sel yang dapat digunakan apabila disimpan dalam gel silika pada suhu bilik. Hasil kajian menunjukkan penghasilan dan keadaan penyimpanan berketahanan tinggi L. plantarum TISTR 2083, boleh digunakan sebagai kultur pemula fermentasi pada masa hadapan dan sebagai probiotik.

Kata kunci: Agen pelindung; kultur pemula: Lactobacillus plantarum; pengeringan suhu rendah

\section{INTRODUCTION}

In food fermentation technology, different types of starter culture have been applied for increasing the capability of fermentation and for controlling the qualities of final products at a desirable level (Holzapfel 2002). Starter powder or the powder form of starter culture has been 
popular for conveniences in preservation, storage, industrial application and use as probiotic (Brachkova et al. 2009; Dimitrellou et al. 2008). Among probiotic microorganisms, starter cultures of lactic acid bacteria (LAB) are industrially important for the fermented food productions (Edward et al. 2011). The strains, used for probiotic application or fermentation as starter culture, should have good technical attributes like: easy to scale up the strain, able to survive on drying process, and able to maintain the viability and functional property during storage (Hou et al. 2016). Lactobacillus is the most common and versatile LAB found in fermented food products, which is widely used as starter culture and important probiotic microorganism (De Vries et al. 2005). L. plantarum has become one of the model microorganisms which has the Generally Recognized as Safe (GRAS) status from the US Food and Drug Administration and attested as Qualified Presumption of Safety (QPS) from the European Food Safety (Seddik et al. 2017; Siezen \& van Hylckama Vlieg 2011). The mostly used commercial media for Lactobacillus growth is MRS (de Man, Rogosa and Sharpe broth); nonetheless, this medium has some disadvantages like complex composition and immoderately expensive for industrial applications (Krzywonos \& Eberhard 2011). Using a lowcost substrate material like sugarcane juice, contains a very good amount of sucrose, for cultivation of important bacteria is alternative to lessen the cost of starter culture production. However, sugarcane is a perennial grass cultivated in tropical Southeast Asia, South Asia, and subtropical areas.

For industrial manufacturing of fermented foods, it is essential to long shelf life and concentrated form of starter culture (Carvalho et al. 2003). The most commonly practiced technique for long-term microbial cell preservation is drying (Iaconelli et al. 2015). Production of an intended dried product with quality attributes at low operating cost is the important objective of the drying process. Different drying process developed for starter culture includes spray drying, freeze-dry, fluidized bed drying, microencapsulation, vacuum drying, drying by desiccation and thermal drying. The microbial preservation by thermal drying has been expanded as the alternative of other high-cost drying methods. Hot air circulating by the oven is a traditional drying technique which involves exposure of solid or liquid materials to a hot air flow that evaporates the solvent or water, leaving behind the final dried product. Due to a simplistic operating mechanism, the hot air oven can reduce the cost compared to other drying methods (Barbosa et al. 2015; Tan et al. 2018). However, drying is the critical step for starter power production because of cell damage during the drying process. Thus, addition of protective agent to microbial cell suspension before starter culture drying can reduce the bacterial loss during drying stage and storage period (Carvalho et al. 2004a; Ying et al. 2010). Different protectants like trehalose, maltodextrin, inulin, sucrose, lactose, sorbitol, skim milk, whey, gelatin, L-glutamate sodium salt, and glucose have been reported to protect microbial cells during different drying process and can increase storage stability (Carvalho et al. 2004a; Hou et al. 2016; Nualkaekul et al. 2012; Santivarangkna et al. 2008; Strasser et al. 2009). Ka-nom Tuay-fu, the spongy rice cake or steam bread, is a traditional fermented food in Thailand which is produced from rice, flour, palm sugar and Loog-pang Khaomak (Maneesri et al. 2018). Loog-pang Khaomak is mixed starter cultures and the key ingredient of Ka-nom Tuay-fu. Lactobacillus plantarum present in Loog-pang Khaomak is the responsible microorganism for the specific acidity flavor and spongy texture that made Ka-nom Tuay-fu as a unique product. This Lactobacillus strain can be used for fermented spongy cake, yogurt and fermented food production. This research aimed to produce high viability $L$. plantarum starter powder with low production cost by using protective agent, application of low-temperature drying and investigate the storage stability.

\section{MATERIALS AND METHODS}

\section{BACTERIAL STRAIN AND INOCULUM PREPARATION}

Potential probiotic strain Lactobacillus plantarum TISTR 2083 was isolated in May-July 2010 from rice cake starter (Loog pang Koawmak) used for traditional Ka-nom Tuay-fu production and collected from Thailand Institute of Scientific and Technological Research (TISTR), Thailand (Maneesri et al. 2018). The strain was inoculated in De Man, Rogosa and Sharpe (MRS) agar, preserved at $4{ }^{\circ} \mathrm{C}$ and sub cultured every month. To prepare seed culture, one loop from the stored culture transferred to a $500 \mathrm{~mL}$ flask containing $200 \mathrm{~mL}$ of MRS broth and incubated at $30^{\circ} \mathrm{C}, 100 \mathrm{rpm}$ shaking speed for $18-24 \mathrm{~h}$ to measure the Optical Density at $600 \mathrm{~nm}\left(\mathrm{OD}_{600}\right)$. The $\mathrm{OD}_{600}$ of seed culture broth was adjusted to $0.5 \pm 0.05$ before experimental inoculation. 


\section{CULTURE MEDIUM AND CELL PREPARATION}

Optimized sugarcane juice was used as substrate medium and it was prepared by standardized to $20^{\circ} \mathrm{Brix}$ total soluble solids (TSS) and 1.5\% (w/v) yeast extract was added as nitrogen source. The sterilized culture medium was inoculated with $5 \%(\mathrm{v} / \mathrm{v})$ of seed culture and incubated for $8 \mathrm{~h}$ at room temperature (about $31^{\circ} \mathrm{C}$ ) with $100 \mathrm{rpm}$ agitation speed. The pellet (L. plantarum TISTR 2083 cells) was collected by centrifugation at $9600 \mathrm{~g}$ for $10 \mathrm{~min}$ at $4{ }^{\circ} \mathrm{C}$ and washed twice with $0.85 \%(\mathrm{w} / \mathrm{v})$ physiological saline.

\section{PROTECTANT AND CARRIER MATERIAL}

To select the good protective agent, the washed pellet was resuspended in five different protectant $(10 \%$, $\mathrm{w} / \mathrm{v})$ : sucrose, trehalose, maltodextrin, skim milk, and L-glutamate sodium salt (L-GSS) and in $0.85 \%(\mathrm{w} / \mathrm{v})$ physiological saline (as control). Afterwards, the protectant with maximum cell viability was prepared at 5,10 , and $15 \%(\mathrm{w} / \mathrm{v})$ to investigate the effect of concentration. In this study, two different carrier material (commercial rice flour and rice starch) was investigated to maximize the cell viability. All the protectants and carrier materials were sterilized by autoclaving at 121 ${ }^{\circ} \mathrm{C}$ for $15 \mathrm{~min}$. The moisture content of rice flour and rice starch were determined before and after sterilization. The rice flour and rice starch had a moisture content of 10.64 and $9.71 \%$ before autoclaved; while 9.25 and $9.11 \%$ after autoclave, respectively.

\section{SAMPLE PREPARATION AND LOW-TEMPERATURE DRYING}

The cell suspension obtained as described earlier was consequently mixed with carrier material with ratio 5 $\mathrm{mL}$ of cell suspension : $5 \mathrm{~g}$ of carrier material. Then the starter culture of L. plantarum TISTR 2083 was dried by using hot air oven at $40{ }^{\circ} \mathrm{C}$ for $16 \mathrm{~h}$. The cell viability was determined before and after drying by standard plate count method. The survival rate is expressed as follows:

$$
\text { Cell survival rate }(\%)=\left(\frac{N}{N_{0}}\right) \times 100
$$

where $\mathrm{N}$ is the number of viable cells after drying; and $\mathrm{N}_{0}$ is the initial viable cell count before drying.
STORAGE OF Lactobacillus plantarum TISTR 2083 POWDER

For storage, $10 \mathrm{~g}$ of dried L. plantarum TISTR 2083 culture was packed in aluminum foil pouch $(11.5 \times 7.5 \mathrm{~cm})$ and sealed properly. Then the dried L. plantarum TISTR 2083 culture containing packets were kept in polyethylene (PE) plastic bag with $1 \mathrm{~g}$ silica gel sachets $(10 \mathrm{~g}$ starter powder : $1 \mathrm{~g}$ silica gel), and without silica gel. Then, the packed powder was stored for 3 months in three different condition : at room temperature with silica gel, at $4{ }^{\circ} \mathrm{C}$ with silica gel and at $4{ }^{\circ} \mathrm{C}$ without silica gel. The cell viability, moisture content and water activity were investigated in 15 days interval.

\section{DETERMINATION OF CELL VIABILITY, WATER ACTIVITY AND MOISTURE CONTENT}

Dried starter powder was rehydrated in $0.85 \%(\mathrm{w} / \mathrm{v})$ physiological saline, followed by serial dilution and viable cells by pour plate method on MRS agar. The moisture of starter powder was determined by AOAC (2000) before and after drying; and the water activity $\left(\mathrm{a}_{\mathrm{w}}\right)$ of the starter was evaluated by $\mathrm{a}_{\mathrm{w}}$ meter.

\section{STATISTICAL ANALYSIS}

All the experimental steps accomplished with 3 replications and the output of ANOVA was expressed as: mean \pm SD. Comparison between the data was analyzed by Duncan's multiple range test and statistical significance level was set at $\mathrm{p} \leq 0.05$.

\section{RESULTS AND DISCUSSION}

\section{SURVIVAL OF L. plantarum TISTR 2083 DURING LOW- TEMPERATURE DRYING USING PROTECTANT}

The effect of sucrose, trehalose, maltodextrin, skim milk, and L-GSS were investigated for survival of $L$. plantarum TISTR 2083 during drying by hot air oven at $40{ }^{\circ} \mathrm{C}$ for $16 \mathrm{~h}$. The cell suspension was mixed with two different carrier materials; rice flour and rice starch, before drying. The combination of protectant and carrier material or separately has effect on cell viability during drying process. The survival rate was observed among treatments of sucrose, trehalose, maltodextrin, skim milk, L-GSS, and control with 84.03, 86.87, 85.91, 93.54, 91.06, and 86.66\%, respectively, for rice flour as carrier support and 83.76, $82.28,82.18,95.11,91.78$, and $79.63 \%$, respectively, 
for rice starch as carrier support (Figure 1). The pellet suspended in skim milk and mixed with rice starch showed maximum survival rate than other treatments. Hou et al. (2016) also reported that sugar-based protectants, monosodium glutamate and skim milk are capable to protect LAB during the dehydration process. The initially viable cells (before drying) in starter culture were 8.91, 9.20, 9.31, 9.16, 9.21, and 9.27 log CFU/g at treatment sucrose, trehalose, maltodextrin, skim milk, L-GSS and control, respectively. However, after drying, the highest viable cell was recorded for skim milk as $8.57 \mathrm{log} \mathrm{CFU} / \mathrm{g}$ with rice flour as carrier support and $8.71 \log$ CFU/g with rice starch as carrier support (Table 1). Skim milk is well known as protective agent for LAB and the presence of protein and calcium are considered as the key factors of protection mechanism of skim milk. Skim milk can protect microorganisms by providing a coating layer, while the calcium ions of skim milk increase the stability of cellular structure and the milk protein may protect the microbial cells from others extracellular degradation mechanisms (Stefanello et al. 2019; Zheng et al. 2015). Sugar materials like trehalose, sucrose help as a protectant by direct interaction with lipid membrane to replace water molecules during dried phase (Romano et al. 2016). The carrier materials also help to protect microorganisms from the adverse environment during the drying process and longtime storage to maintain the viability of the cell. The majority of rice starch has 2-7 $\mu \mathrm{m}$ particle sizes and rice flour particles have sizes of about 45-150 $\mu \mathrm{m}$ (Murakami et al. 2016; Wani et al. 2012). The smaller particle size of rice starch offers better protection by making outer coating layer and the high starch content gives protection from high temperature. Meanwhile, amylopectin content in rice starch has ability to bind water product, so that microbial cell entrapped by coating layer could protected during thermal drying (Alonso 2016).

Before drying, the moisture content of L. plantarum TISTR 2083 cultures were in a range of a maximum $51.56 \pm 0.53$ in control treatment with rice flour and minimum $47.45 \pm 1.61(\%)$ in skim milk treatment with rice starch (Table 2). After drying, the range of moisture content between maximum $10.82 \pm 2.15$ in maltodextrin treatment with rice flour and minimum $9.00 \pm 1.32(\%)$ in trehalose treatment with rice flour. The starter powder of skim milk treatment with rice starch was high in cell viability $8.71 \log \mathrm{CFU} / \mathrm{g}$ ) and moisture content was $10.00 \pm 2.01(\%)$. Moisture content is significantly related to drying efficiency and has a further effect on microbial and technical properties of dried starter powder (Tan et al. 2011). There was no relation between higher water activity recorded for higher moisture content before drying. Yet, after drying, water activity of $L$. plantarum TISTR 2083 culture was $0.423 \pm 0.020,0.419 \pm 0.018$, $0.420 \pm 0.018,0.427 \pm 0.024,0.435 \pm 0.024$, and $0.434 \pm 0.023$ at treatment sucrose, trehalose, maltodextrin, skim milk, L-GSS, and control, respectively, with rice flour as carrier material and correspondingly $0.427 \pm 0.022$, $0.418 \pm 0.017,0.418 \pm 0.021,0.421 \pm 0.016,0.447 \pm 0.024$, and $0.437 \pm 0.022$ with rice starch as carrier material (Table 3 ). Therefore, from the concern of maximum cell survival rate during drying, skim milk was selected as protective agent with rice starch as carrier material for L. plantarum TISTR 2083 powder production.

\section{EFFECT OF SKIM MILK CONCENTRATION ON SURVIVAL OF L. plantarum TISTR 2083}

Different concentrations of skim milk powder investigated to check the effect on survival of L. plantarum TISTR 2083 during drying. The increase of skim milk amount from 5 to $10 \%(\mathrm{w} / \mathrm{v})$ increased the cell viability during hot-air oven drying. On the other hand, the higher amount of skim milk, $15 \%(\mathrm{w} / \mathrm{v})$, did not represented a significantly protective effect during drying by heat treatment (Figure 2). However, the survival rate of L. plantarum TISTR 2083 at 5, 10, and $15 \%(\mathrm{w} / \mathrm{v})$ skim milk treatments were $87.66 \pm 0.89$, $92.17 \pm 1.06$, and $92.05 \pm 0.10(\%)$, respectively. The cell viability of dried powder was recorded with $8.13 \pm 0.08$, $8.35 \pm 0.10$, and $8.39 \pm 0.09 \log \mathrm{CFU} / \mathrm{g}$ at protectant 5,10 and $15 \%(\mathrm{w} / \mathrm{v})$ skim milk, respectively (Table 4). Thus, the increase of the amount of skim milk after $10 \%(\mathrm{w} / \mathrm{v})$ not protecting the cell significantly during drying. There are also similar results found by Hou et al. (2016), 10\% $(\mathrm{w} / \mathrm{v})$ of skim milk with other protectants showed higher cell viability than 8 or $12 \%(\mathrm{w} / \mathrm{v})$ skim milk. Generally, reconstituted skim milk powder is a suitable protectant (Romano et al. 2016). Besides, the presence of calcium ions in skim milk may provide protective effects (Stefanello et al. 2019). There was a reverse relation between the moisture content of L. plantarum TISTR 2083 culture and the skim milk concentration. The moisture contents of L. plantarum TISTR 2083 culture before drying were $52.69 \pm 1.79,49.23 \pm 0.45$, and $45.65 \pm 0.90$ (\%) at treatments of 5,10, and $15 \%(\mathrm{w} / \mathrm{v})$ skim milk, respectively (Table 4). The higher solute (skim milk) concentration desired to contain low unbound water leaded to the lower moisture content of the initial state of starter culture. The final moisture after drying was 
recorded with $8.68 \pm 0.09,8.51 \pm 0.18$, and $8.04 \pm 0.12 \%$ $(\mathrm{w} / \mathrm{v})$ at treatments of 5,10 , and $15 \%(\mathrm{w} / \mathrm{v})$ skim milk, respectively. It is recommended to keep lower moisture content for storage stability, however, it is possible to obtain higher moisture content depending on types of carrier agents and drying techniques (Arslan et al. 2015; Guergoletto et al. 2017). A similar trend was also observed in initial water activity before drying. The higher water activity was recorded for the sample that contained more moisture content. Yet, after drying, the water activity was $0.374 \pm 0.017,0.380 \pm 0.014$, and $0.369 \pm 0.001$ at treatments of 5,10 , and $15 \%(\mathrm{w} / \mathrm{v})$ skim milk, respectively (Table 4). To sum up, the decrease of skim milk resulted lower protection during drying while increase of skim milk didn't affect significantly. Thus $10 \%$ (w/v) skim milk was continued for next steps.

\section{STABILITY OF L. plantarum TISTR 2083 POWDER IN STORAGE}

Dried L. plantarum TISTR 2083 was stored in aluminum foil pouch for 3 months in three storage conditions namely, at room temperature (RT) with silica gel, at 4 ${ }^{\circ} \mathrm{C}$ temperature with silica gel and in $4{ }^{\circ} \mathrm{C}$ temperature without silica gel. The cell viability, moisture content and water activity were investigated in 15 days interval but no data recorded for $75^{\text {th }}$ day due to COVID-19 pandemic situation.

There was significant difference in cell survival rate during storage in room temperature and $4{ }^{\circ} \mathrm{C}$ temperature with or without silica gel (Figure 3). After 90 days of storage, there was no viable cell that stored at room temperature with silica gel, while starter culture at $4{ }^{\circ} \mathrm{C}$ had 85.32 and $84.17 \%$ survival rate with silica gel and without silica gel, respectively. The relationship between storage temperature and cell mortality is well established and protectants may unable to protect cells at higher storage temperatures (Champagne et al. 1996). Lapsiri et al. (2012) reported that, $25^{\circ} \mathrm{C}$ was crucial storage temperature for spray-dried L. plantarum TISTR 2075, which led to a great decrease in viable cell number. At room temperature, L. plantarum TISTR 2083 was stored with silica gel, but there was no viable cell after 90 days storage, while moisture content increased significantly $(\mathrm{p} \leq 0.05)$ and water activity insignificantly (Figure 4). At $4{ }^{\circ} \mathrm{C}$ temperature with silica gel, cell viability of $L$. plantarum TISTR 2083 after 90 days was $7.87 \pm 0.07 \log$ CFU/g (Figure 5). Moisture content of L. plantarum TISTR 2083 also increased significantly $(\mathrm{p} \leq 0.05)$, while water activity also changed slightly. At $4{ }^{\circ} \mathrm{C}$ temperature without silica gel, cell viability of $L$. plantarum TISTR 2083 after end of storage period was $7.87 \pm 0.07 \mathrm{log}$ CFU/g (Figure 6), moisture content changed significantly $(\mathrm{p} \leq 0.05)$, while there was no significant change in water activity. Normally silica gel plays an important role to maintain moisture content and cell viability during storage. Carvalho et al. (2004b) have reported that different factors like higher temperature, amount of available oxygen, and water activity are responsible for the cell viability during storage duration. Additionally, Hou et al. (2016) reported that starter powder storage in higher temperature $\left(25^{\circ} \mathrm{C}\right)$ meant lower viable cells at the end of storage. However, the L. plantarum TISTR 2083 starter powder stored in $4{ }^{\circ} \mathrm{C}$ temperature with or without silica gel could be used for 3 months since it showed over $80 \%$ survival rate.

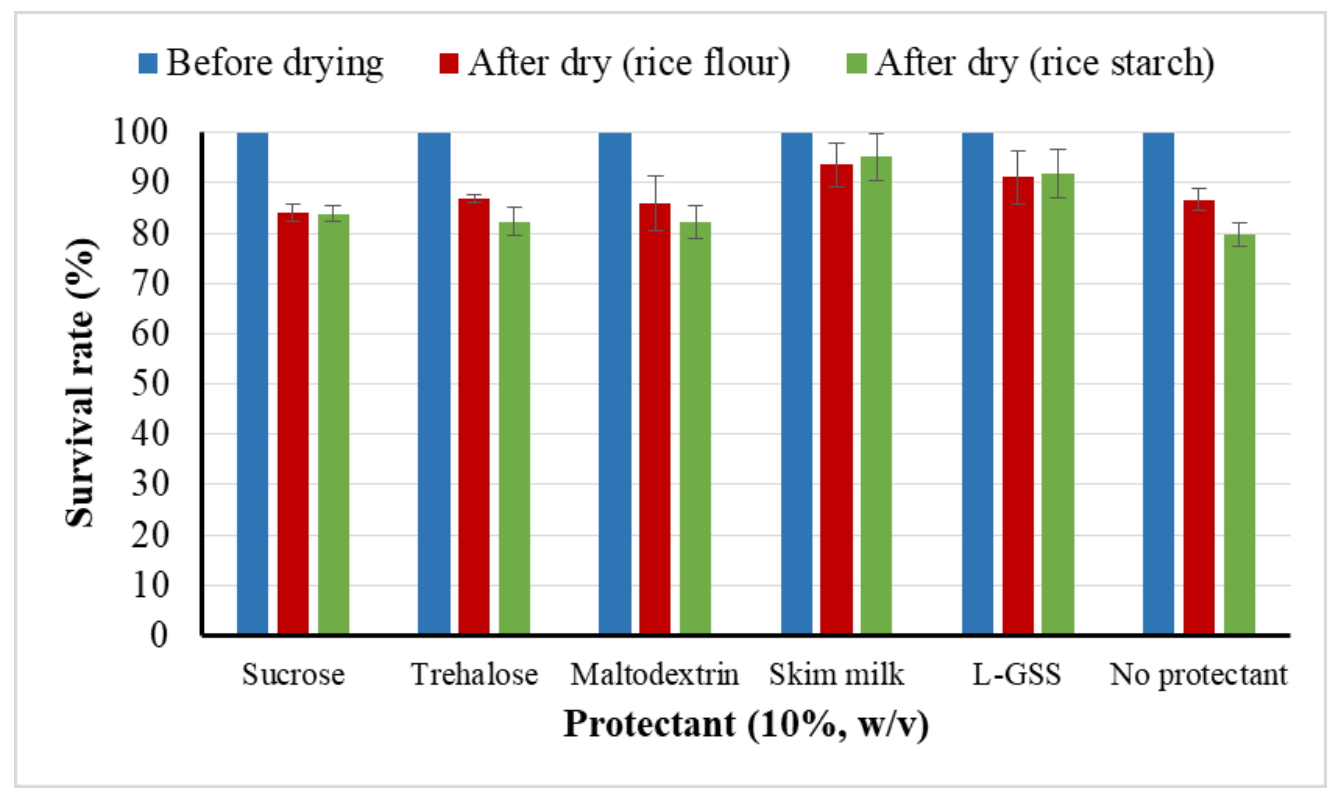

FIGURE 1. Survival rate of L. plantarum TISTR 2083 culture during drying in $10 \%(\mathrm{w} / \mathrm{v})$ different protectants with different carriers 


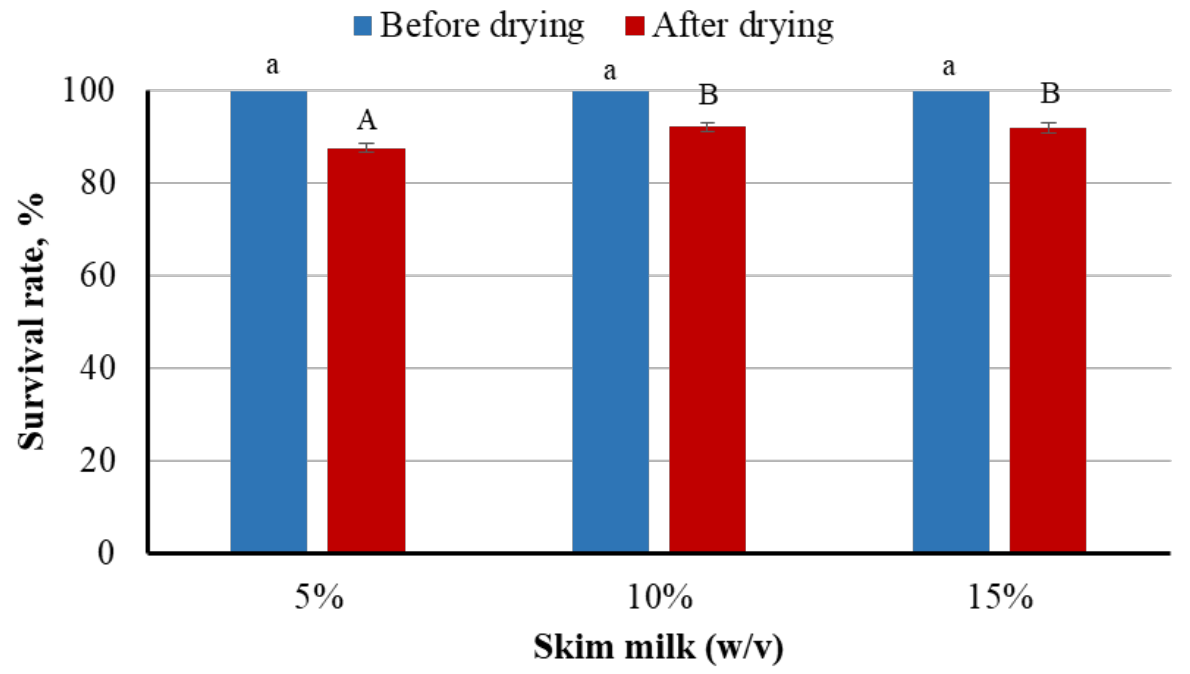

FIGURE 2. Survival rate of $L$. plantarum TISTR 2083 at 5, 10 and $15 \%$ skim milk. Significant difference represented by small letters for before drying and capital letters for after drying

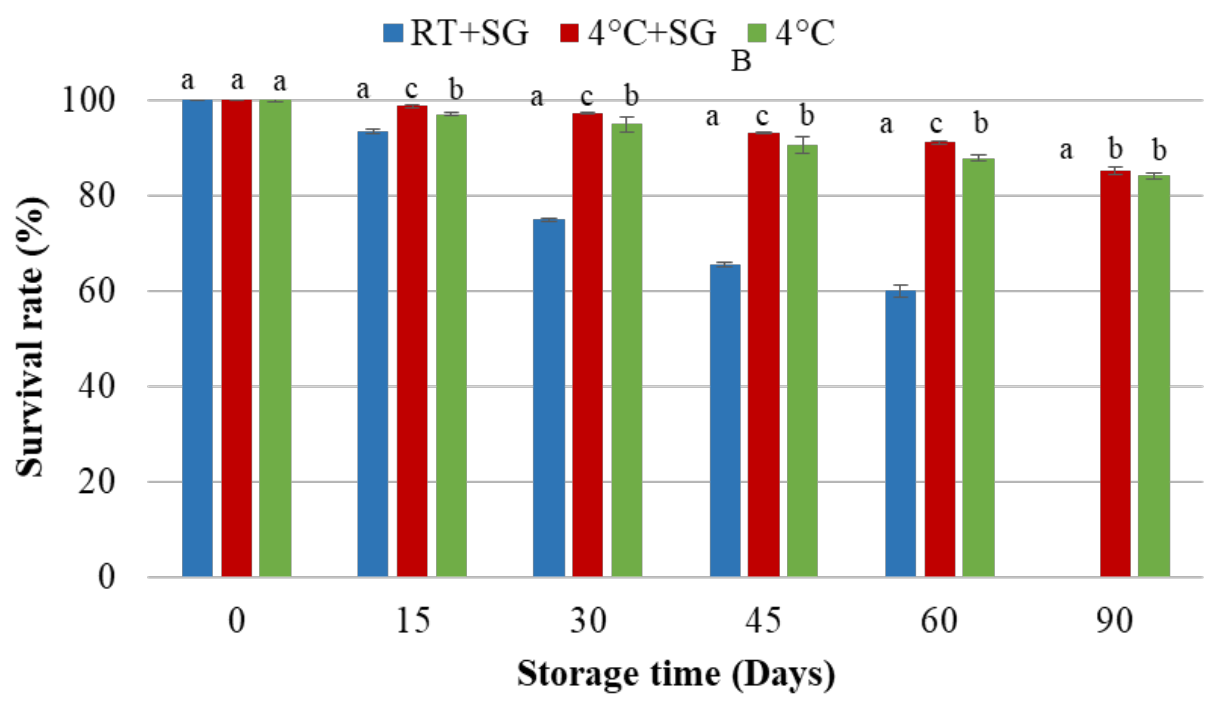

FIGURE 3. Survival rate of $L$. plantarum TISTR 2083 starter powder in different storage conditions (RT-room temperature, SG-silica gel). Significant difference represented by different letters for same day 


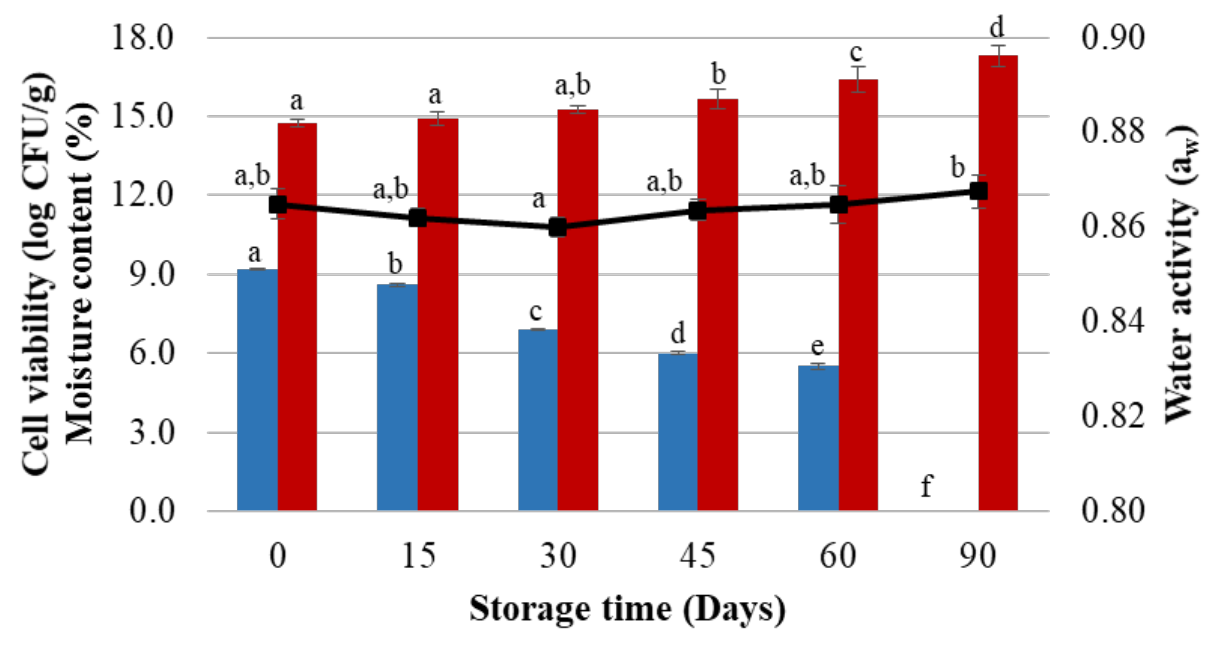

Cell viability $\rightarrow$ Moisture content $\rightarrow$ Water activity

FIGURE 4. Cell viability, moisture content and water activity of dried L. plantarum TISTR 2083 culture in room temperature with silica gel.

Significant difference represented by different small letters

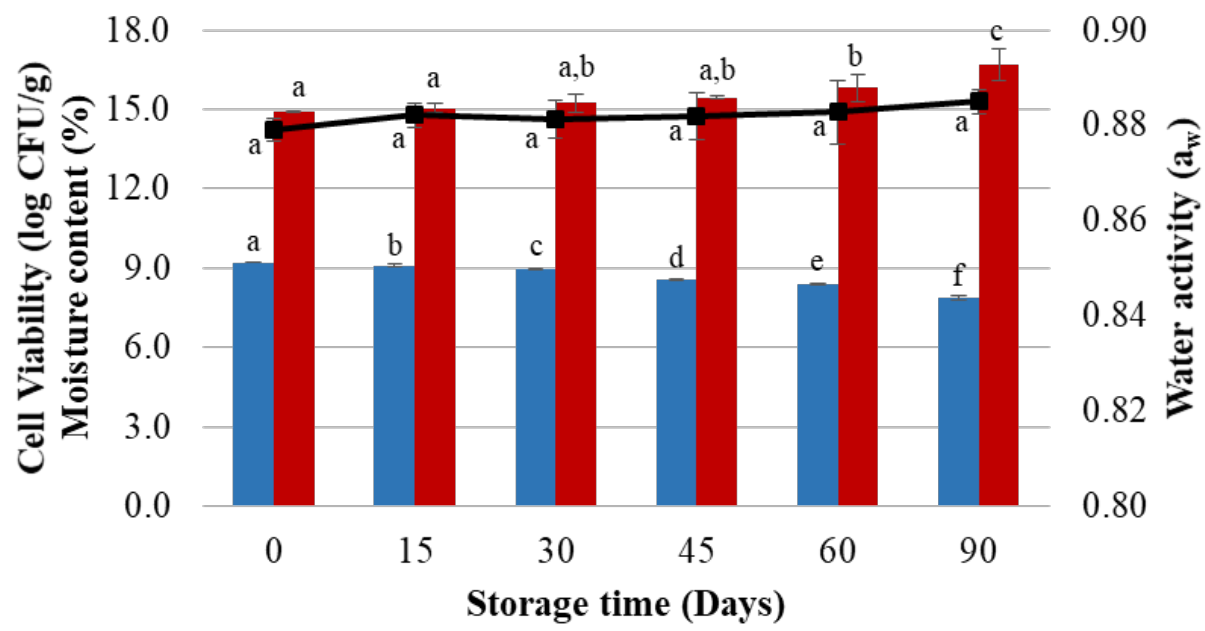

Cell viability $\square$ Moisture content $\rightarrow$ Water activity

FIGURE 5. Cell viability, moisture content and water activity of dried L. plantarum TISTR 2083 culture in $4{ }^{\circ} \mathrm{C}$ temperature with silica gel. Significant difference represented by different small letters 


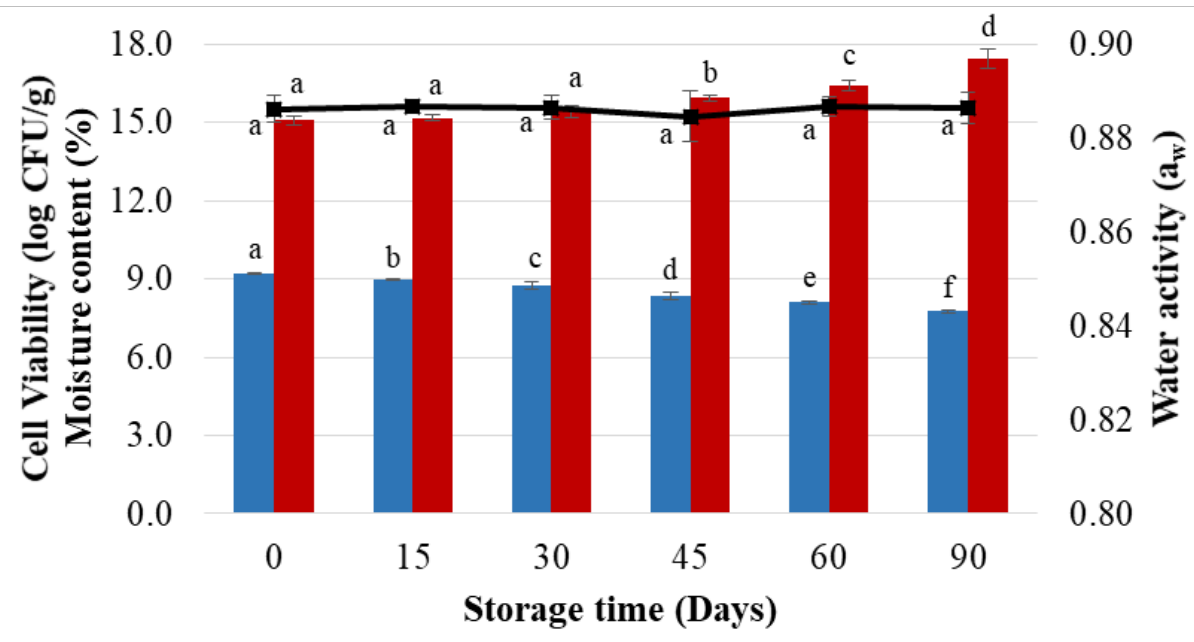

Cell viability $\quad$ Moisture content $\rightarrow$ Water activity

FIGURE 6. Cell viability, moisture content and water activity of dried

L. plantarum TISTR 2083 culture in $4{ }^{\circ} \mathrm{C}$ temperature without silica gel. Significant difference represented by different small letters

TABLE 1. Cell viability of L. plantarum TISTR 2083 starter powder in 10\% (w/v) different protectants with different carriers

\begin{tabular}{|c|c|c|c|}
\hline Analysis & Treatments & Rice flour & Rice starch \\
\hline \multirow{6}{*}{ Cell viability $(\log \mathrm{CFU} / \mathrm{g})$} & Sucrose & $7.48 \pm 0.15^{\mathrm{a}, \mathrm{A}}$ & $7.46 \pm 0.14^{\mathrm{a}, \mathrm{A}}$ \\
\hline & Trehalose & $7.99 \pm 0.08^{\mathrm{a}, \mathrm{A}, \mathrm{B}}$ & $7.57 \pm 0.26^{\mathrm{a}, \mathrm{A}}$ \\
\hline & Maltodextrin & $8.00 \pm 0.51^{\mathrm{a}, \mathrm{A}, \mathrm{B}}$ & $7.65 \pm 0.31^{\mathrm{a}, \mathrm{A}}$ \\
\hline & Skim milk & $8.57 \pm 0.40^{\mathrm{a}, \mathrm{B}}$ & $8.71 \pm 0.42^{\mathrm{a}, \mathrm{B}}$ \\
\hline & L-GSS & $8.38 \pm 0.48^{\mathrm{a}, \mathrm{B}}$ & $8.45 \pm 0.44^{\mathrm{a}, \mathrm{B}}$ \\
\hline & No protectant & $8.04 \pm 0.19^{\mathrm{a}, \mathrm{A}, \mathrm{B}}$ & $7.38 \pm 0.22^{\mathrm{b}, \mathrm{A}}$ \\
\hline
\end{tabular}

Each value is the average of three measurements \pm standard deviation; a-b means a row with different letters are significantly different ( $\mathrm{p} \leq 0.05$ ) at $95 \%$ level of confidence A-B means a column with different letters are significantly different $(\mathrm{p} \leq 0.05)$ at $95 \%$ level of confidence 
TABLE 2. Moisture content of L. plantarum TISTR 2083 culture dried with different protectant

\begin{tabular}{|c|c|c|c|c|}
\hline Analysis & Protectants & Carriers & Before drying & After drying \\
\hline \multirow{12}{*}{$\begin{array}{l}\text { Moisture content } \\
(\%)\end{array}$} & \multirow{2}{*}{ Sucrose } & Rice flour & $49.91 \pm 0.57^{\mathrm{a}, \mathrm{B}, \mathrm{C}, \mathrm{D}, \mathrm{E}}$ & $9.47 \pm 0.75^{\mathrm{b}, \mathrm{A}}$ \\
\hline & & Rice starch & $49.31 \pm 1.09^{\mathrm{a}, \mathrm{A}, \mathrm{B}, \mathrm{C}, \mathrm{D}}$ & $9.52 \pm 1.37^{\mathrm{b}, \mathrm{A}}$ \\
\hline & \multirow{2}{*}{ Trehalose } & Rice flour & $49.05 \pm 0.90^{\mathrm{a}, \mathrm{A}, \mathrm{B}, \mathrm{C}}$ & $9.00 \pm 1.32^{\mathrm{b}, \mathrm{A}}$ \\
\hline & & Rice starch & $48.59 \pm 1.00^{\mathrm{a}, \mathrm{A}, \mathrm{B}, \mathrm{C}}$ & $9.90 \pm 1.84^{\mathrm{b}, \mathrm{A}}$ \\
\hline & \multirow{2}{*}{ Maltodextrin } & Rice flour & $50.15 \pm 0.48^{\mathrm{a}, \mathrm{B}, \mathrm{C}, \mathrm{D}, \mathrm{E}}$ & $10.82 \pm 2.15^{\mathrm{b}, \mathrm{A}}$ \\
\hline & & Rice starch & $48.26 \pm 1.04^{\mathrm{a}, \mathrm{A}, \mathrm{B}}$ & $10.19 \pm 1.47^{\mathrm{b}, \mathrm{A}}$ \\
\hline & \multirow{2}{*}{ Skim milk } & Rice flour & $50.48 \pm 0.30^{\mathrm{a}, \mathrm{C}, \mathrm{D}, \mathrm{E}}$ & $9.89 \pm 1.72^{\mathrm{b}, \mathrm{A}}$ \\
\hline & & Rice starch & $47.45 \pm 1.61^{\mathrm{a}, \mathrm{A}}$ & $10.00 \pm 2.01^{\mathrm{b}, \mathrm{A}}$ \\
\hline & \multirow{2}{*}{ L-GSS } & Rice flour & $48.82 \pm 0.44^{\mathrm{a}, \mathrm{A}, \mathrm{B}, \mathrm{C}}$ & $9.92 \pm 1.68^{\mathrm{b}, \mathrm{A}}$ \\
\hline & & Rice starch & $50.60 \pm 2.55^{\mathrm{a}, \mathrm{C}, \mathrm{D}, \mathrm{E}}$ & $10.25 \pm 2.31^{\mathrm{b}, \mathrm{A}}$ \\
\hline & \multirow{2}{*}{ No protectant } & Rice flour & $51.56 \pm 0.53^{\mathrm{a}, \mathrm{E}}$ & $10.47 \pm 1.71^{\mathrm{b}, \mathrm{A}}$ \\
\hline & & Rice starch & $51.38 \pm 1.10^{\mathrm{a}, \mathrm{D}, \mathrm{E}}$ & $10.50 \pm 1.22^{\mathrm{b}, \mathrm{A}}$ \\
\hline
\end{tabular}

Each value is the average of three measurements \pm standard deviation; a-b means a row with different letters are significantly different ( $\leq \leq 0.05$ ) at $95 \%$ level of confidence; A-B means a column with different letters are significantly different $(\mathrm{p} \leq 0.05)$ at $95 \%$ level of confidence

TABLE 3. Water activity of L. plantarum TISTR 2083 culture dried with different protectant

\begin{tabular}{|c|c|c|c|c|}
\hline Analysis & Protectants & Carriers & Before drying & After drying \\
\hline \multirow{12}{*}{ Water activity $\left(\mathrm{a}_{\mathrm{w}}\right)$} & \multirow{2}{*}{ Sucrose } & Rice flour & $0.998 \pm 0.001^{\mathrm{a}, \mathrm{A}}$ & $0.423 \pm 0.020^{\mathrm{b}, \mathrm{A}}$ \\
\hline & & Rice starch & $0.994 \pm 0.001^{\mathrm{a}, \mathrm{C}, \mathrm{D}}$ & $0.427 \pm 0.022^{\mathrm{b}, \mathrm{A}}$ \\
\hline & \multirow{2}{*}{ Trehalose } & Rice flour & $0.994 \pm 0.002^{\mathrm{a}, \mathrm{C}, \mathrm{D}}$ & $0.419 \pm 0.018^{\mathrm{b}, \mathrm{A}}$ \\
\hline & & Rice starch & $0.994 \pm 0.001^{\mathrm{a}, \mathrm{D}}$ & $0.418 \pm 0.017^{\mathrm{b}, \mathrm{A}}$ \\
\hline & \multirow{2}{*}{ Maltodextrin } & Rice flour & $0.997 \pm 0.001^{\mathrm{a}, \mathrm{A}, \mathrm{B}}$ & $0.420 \pm 0.018^{\mathrm{b}, \mathrm{A}}$ \\
\hline & & Rice starch & $0.998 \pm 0.001^{\mathrm{a}, \mathrm{A}}$ & $0.418 \pm 0.021^{\mathrm{b}, \mathrm{A}}$ \\
\hline & \multirow{2}{*}{ Skim milk } & Rice flour & $0.998 \pm 0.001^{\mathrm{a}, \mathrm{A}}$ & $0.427 \pm 0.024^{\mathrm{b}, \mathrm{A}}$ \\
\hline & & Rice starch & $0.995 \pm 0.001^{\mathrm{a}, \mathrm{B}, \mathrm{C}, \mathrm{D}}$ & $0.421 \pm 0.016^{\mathrm{b}, \mathrm{A}}$ \\
\hline & \multirow{2}{*}{ L-GSS } & Rice flour & $0.989 \pm 0.001^{\mathrm{a}, \mathrm{E}}$ & $0.435 \pm 0.024^{\mathrm{b}, \mathrm{A}}$ \\
\hline & & Rice starch & $0.983 \pm 0.002^{\mathrm{a}, \mathrm{F}}$ & $0.447 \pm 0.024^{\mathrm{b}, \mathrm{A}}$ \\
\hline & \multirow{2}{*}{ No protectant } & Rice flour & $0.995 \pm 0.002^{\mathrm{a}, \mathrm{B}, \mathrm{C}, \mathrm{D}}$ & $0.434 \pm 0.023^{\mathrm{b}, \mathrm{A}}$ \\
\hline & & Rice starch & $0.997 \pm 0.002^{\mathrm{a}, \mathrm{A}, \mathrm{B}, \mathrm{C}}$ & $0.437 \pm 0.022^{\mathrm{b}, \mathrm{A}}$ \\
\hline
\end{tabular}

Each value is the average of three measurements \pm standard deviation; a-b means a row with different letters are significantly different ( $\leq \leq 0.05$ ) at $95 \%$ level of confidence; A-B means a column with different letters are significantly different $(\mathrm{p} \leq 0.05)$ at $95 \%$ level of confidence 
TABLE 4. The cell viability, moisture content and water activity of L. plantarum TISTR 2083 culture at 5 , 10 and $15 \%$ skim milk concentration

\begin{tabular}{|c|c|c|c|}
\hline Analysis & Treatments & Before drying & After drying \\
\hline \multirow{3}{*}{$\begin{array}{l}\text { Cell viability } \\
\text { (log CFU/g) }\end{array}$} & $5 \%(\mathrm{w} / \mathrm{v})$ skim milk & $9.28 \pm 0.06^{\mathrm{a}, \mathrm{A}}$ & $8.13 \pm 0.08^{\mathrm{b}, \mathrm{A}}$ \\
\hline & $10 \%(\mathrm{w} / \mathrm{v})$ skim milk & $9.06 \pm 0.06^{\mathrm{a}, \mathrm{B}}$ & $8.35 \pm 0.10^{\mathrm{b}, \mathrm{B}}$ \\
\hline & $15 \%(\mathrm{w} / \mathrm{v})$ skim milk & $9.11 \pm 0.09^{\mathrm{a}, \mathrm{B}}$ & $8.39 \pm 0.09^{\mathrm{b}, \text { в }}$ \\
\hline \multirow{3}{*}{$\begin{array}{l}\text { Moisture content } \\
(\%)\end{array}$} & $5 \%(\mathrm{w} / \mathrm{v})$ skim milk & $52.69 \pm 1.79^{\mathrm{a}, \mathrm{A}}$ & $8.68 \pm 0.09^{\mathrm{b}, \mathrm{A}}$ \\
\hline & $10 \%(\mathrm{w} / \mathrm{v})$ skim milk & $49.23 \pm 0.45^{\mathrm{a}, \mathrm{B}}$ & $8.51 \pm 0.18^{\mathrm{b}, \mathrm{A}}$ \\
\hline & $15 \%(\mathrm{w} / \mathrm{v})$ skim milk & $45.65 \pm 0.90^{\mathrm{a}, \mathrm{C}}$ & $8.04 \pm 0.12^{\mathrm{b}, \mathrm{B}}$ \\
\hline \multirow{3}{*}{ Water activity $\left(\mathrm{a}_{\mathrm{w}}\right)$} & $5 \%(\mathrm{w} / \mathrm{v})$ skim milk & $0.998 \pm 0.002^{\mathrm{a}, \mathrm{A}}$ & $0.374 \pm 0.017^{\mathrm{b}, \mathrm{A}}$ \\
\hline & $10 \%(\mathrm{w} / \mathrm{v})$ skim milk & $0.993 \pm 0.002^{\mathrm{a}, \mathrm{B}}$ & $0.380 \pm 0.014^{\mathrm{b}, \mathrm{A}}$ \\
\hline & $15 \%(\mathrm{w} / \mathrm{v})$ skim milk & $0.990 \pm 0.001^{\mathrm{a}, \mathrm{B}}$ & $0.369 \pm 0.001^{\mathrm{b}, \mathrm{A}}$ \\
\hline
\end{tabular}

Each value is the average of three measurements \pm standard deviation; a-b means a row with different letters are significantly different ( $\mathrm{p} \leq 0.05$ ) at $95 \%$ level of confidence; A-B means a column with different letters are significantly different $(\mathrm{p} \leq 0.05)$ at $95 \%$ level of confidence

\section{CONCLUSION}

In this research, sugarcane juice was used as cheap substrate medium to cultivate L. plantarum TISTR 2083 with objective of starter powder production. Skim milk as protectant with supporting material rice starch showed highest survival of L. plantarum TISTR 2083 starter culture during low-temperature drying by hot air oven that resulted in 95\% survival rate (cell viability $8.71 \mathrm{log}$ $\mathrm{CFU} / \mathrm{g}$ ). It was effective in storing the dried starter culture at $4{ }^{\circ} \mathrm{C}$ temperature. After 90 days of storage, starter powder stored at $4{ }^{\circ} \mathrm{C}$ with silica gel and without silica gel had 7.87 and $7.77 \log$ CFU/g cell viability, 85.32, and $84.17 \%$ survival rate, respectively; while there was no viable cell that stored in room temperature with silica gel. So the starter powder stored in $4{ }^{\circ} \mathrm{C}$ temperature can be used for 3 months. However, in further study, the fermentation efficiency of dried culture during the storage period should be investigate to further improvement and better application. Despite that, this research was based on starter powder production with application of simple and low-cost drying method, that showed the efficiency of high viable L. plantarum TISTR 2083 production and high survival rate during storage.

\section{ACKNOWLEDGEMENTS}

This work was supported by Thailand's Education Hub for ASEAN Countries (TEH-AC) scholarship and a research grant provided by the Graduate School, Prince of Songkla University.

\section{REFERENCES}

Alonso, S. 2016. Novel preservation techniques for microbial cultures. In Series on Novel Food Fermentation Technologies, edited by Ojha, K.S. \& Tiwari, B.K. Switzerland: Springer International Publishing. pp. 7-33.

AOAC. 2000. Official Methods of Analysis. The Association of Official Analysis Chemistry (AOAC).

Arslan, S., Erbas, M., Tontul, I. \& Topuz, A. 2015. Microencapsulation of probiotic Saccharomyces cerevisae var. boulardii with different wall materials by spray drying. Food Science and Technology 63(1): 685-690.

Barbosa, J., Borges, S., Amorim, M., Pereira, M.J., Oliveira, A., Pintado, M.E. \& Teixeira, P. 2015. Comparison of spray drying, freeze drying and convective hot air drying for the production of a probiotic orange powder. Journal of Functional Foods 17: 340-351.

Brachkova, M.I., Duarte, A. \& Pinto, J.F. 2009. Evaluation of the viability of Lactobacillus spp. after the production of different solid dosage forms. Journal of Pharmaceutical Sciences 98(9): 3329-3339. 
Carvalho, A.S., Silva, J., Ho, P., Teixeira, P., Malcata, F.X. \& Gibbs, P. 2004a. Effects of various sugars added to growth and drying media upon thermotolerance and survival throughout storage of freeze-dried Lactobacillus delbrueckii ssp. bulgaricus. Biotechnology Progress 20(1): 248-254.

Carvalho, A.S., Silva, J., Ho, P., Teixeira, P., Malcata, F.X. \& Gibbs, P. 2004b. Relevant factors for the preparation of freeze-dried lactic acid bacteria. International Dairy Journal 14(10): 835-847.

Carvalho, A.S., Silva, J.H., Teixera, P., Malcata, F.X. \& Gibbs, P. 2003. Impedimetric method for estimating the residual activity of freeze-dried Lactobacillus delbrueckii ssp. bulgaricus. International Dairy Journal 13(6): 463468.

Champagne, C.C., Mondou, F., Raymond, Y. \& Roy, D. 1996. Effect of polymers and storage temperature on the stability of freeze-dried lactic acid bacteria. Food Research International 29(5-6): 555-562.

De Vries, M.C., Vaughan, E.E., Kleerebezem, M. \& de Vos, W.M. 2005. Lactobacillus plantarum - survival, functional and potential probiotic properties in the human intestinal tract. International Dairy Journal 16(9): 1018-1028.

Dimitrellou, D., Tsaousi, K., Kourkoutas, Y., Panas, P., Kanellaki, M. \& Koutinas, A.A. 2008. Fermentation efficiency of thermally dried immobilized kefir on casein as starter culture. Process Biochemistry 43(12): 1323-1329.

Edward, V.A., Huch, M., Dortu, C., Thonart, P., Egounlety, M., Van Zyl, P.J., Singh, S., Holzapfel, W.H. \& Franz, C.M.A.P. 2011. Biomass production and small-scale testing of freeze-dried lactic acid bacteria starter strains for cassava fermentations. Food Control 22(3-4): 389-395.

Guergoletto, K.B., Busanello, M. \& Garcia, S. 2017. Influence of carrier agents on the survival of Lactobacillus reuteri LR92 and the physicochemical properties of fermented juçara pulp produced by spray drying. Food Science and Technology 80: 321-327.

Holzapfel, W.H. 2002. Appropriate starter culture technologies for small-scale fermentation in developing countries. International Journal of Food Microbiology 75(3): 197-212.

Hou, B., Wang, H., Yan, T., Shan, S., Zhou, W., Zhang, L., Man, C., Deng, Y. \& Jiang, Y. 2016. Production for high-vitality starter culture of Lactobacillus plantarum NDC 75017 by high cell-density cultivation and low-temperature vacuum drying. Food Science and Technology Research 22(4): 519-527.

Iaconelli, C., Lemetais, G., Kechaou, N., Chain, F., BermúdezHumarán, L.G., Langella, P., Gervais, P. \& Beney, L. 2015. Drying process strongly affects probiotics viability and functionalities. Journal of Biotechnology 214: 17-26.

Krzywonos, M. \& Eberhard, T. 2011. High density process to cultivate Lactobacillus plantarum biomass using wheat stillage and sugar beet molasses. Electronic Journal of Biotechnology 14(2): 1-9.
Lapsiri, W., Bhandari, B. \& Wanchaitanawong, P. 2012: Viability of Lactobacillus plantarum TISTR 2075 in different protectants during spray drying and storage. Drying Technology: An International Journal 30(13): 1407-1412.

Maneesri, J., Masniyom, P. \& Liming, M. 2018. Survival of Candida tropicalis and Lactobacillus plantarum starter culture after using protective agent and drying. International Food Research Journal 25(4): 1655-1660.

Murakami, S., Kuramochi, M., Koda, T., Nishio, T. \& Nishioka, A. 2016. Relationship between rice flour particle sizes and expansion ratio of pure rice bread. Journal of Applied Glycoscience 63(1): 19-22.

Nualkaekul, S., Deepika, G. \& Charalampopoulos, D. 2012. Survival of freeze dried Lactobacillus plantarum in instant fruit powders and reconstituted fruit juices. Food Research International 48(2): 627-633.

Romano, N., Tymczyszyn, E., Mobili, P. \& Gomez-Zavaglia, A. 2016. Prebiotics as protectants of lactic acid bacteria. In Probiotics, Prebiotics, and Synbiotics: Bioactive Foods in Health Promotion, edited by Watson, R.R. \& Preedy, V.R. Amsterdam: Elsevier. pp. 155-163.

Santivarangkna, C., Higl, B. \& Forest, P. 2008. Protection mechanisms of sugars during different stages of preparation process of dried lactic acid starter cultures. Food Microbiology 25(3): 429-441.

Seddik, H.A., Bendali, F., Gancel, F., Fliss, I., Spano, G. \& Drider, D. 2017. Lactobacillus plantarum and its probiotic and food potentialities. Probiotics and Antimicrobial Proteins 9(2): 111-122.

Siezen, R.J. \& van Hylckama Vlieg, J.E. 2011. Genomic diversity and versatility of Lactobacillus plantarum, a natural metabolic engineer. Microbial Cell Factories 10(1): 1-13.

Strasser, S., Neureiter, M., Geppl, M., Braun, R. \& Danner, H. 2009. Influence of lyophilization, fluidized bed drying, addition of protectants, and storage on the viability of lactic acid bacteria. Journal of Applied Microbiology 107(1): 167-177.

Stefanello, R.F., Nabeshima, E.H., Iamanaka, B.T., Ludwig, A., Fries, L.L.M., Bernardi, A.O. \& Copetti, M.V. 2019. Survival and stability of Lactobacillus fermentum and Wickerhamomyces anomalus strains upon lyophilisation with different cryoprotectant agents. Food Research International 115: 90-94.

Tan, D.T., Poh, P.E. \& Chin, S.K. 2018. Microorganism preservation by convective air-drying - A review. Drying Technology: An International Journal 36(7): 764-779.

Tan, L.W., Ibrahim, M.N., Kamil, R. \& Taip, F.S. 2011. Empirical modeling for spray drying process of stick and non-stick products. Procedia Food Science 1: 690-697.

Taskila, S. 2017. Industrial production of starter cultures. In Starter Culture in Food Production, edited by Speranza, B., Bevilacqua, A., Corbo M.R. \& Sinigaglia, M. New Jersey: John Wiley \& Sons. pp. 79-100. 
Wani, A.A., Singh, P., Shah, M.A., Schweiggert-Weisz, U., Gul, K. \& Wani, I.A. 2012. Rice starch diversity: Effects on structural, morphological, thermal, and physicochemical properties - A review. Comprehensive Reviews in Food Science and Food Safety 11(5): 417-436.

Ying, D.Y., Phoon, M.C., Sanguansri, L., Weerakkody, R., Burgar, I. \& Augustin, M.A. 2010. Microencapsulated Lactobacillus rhamnosus GG powders: Relationship of powder physical properties to probiotic survival during storage. Journal of Food Science 75(9): 588-595.

Zheng, X., Fu, N., Duan, M., Woo, M.W., Selomulya, C. \& Chen, X.D. 2015. The mechanisms of the protective effects of reconstituted skim milk during convective droplet drying of lactic acid bacteria. Food Research International 76(3): 478-488
Abdullah Al Mamun \& Jaruwan Maneesri* Department of Food Science and Nutrition Faculty of Science and Technology

Prince of Songkla University

Pattani 94000

Thailand

Payap Masniyom

Department of Technology and Industry

Faculty of Science and Technology

Prince of Songkla University

Pattani 94000

Thailand

*Corresponding author; email: jaruwan.ma@psu.ac.th

Received: 25 August 2020

Accepted: 20 December 2020 